\title{
FACTORS ASSOCIATED WITH INFECTIONS IN SPINAL SURGERY
}

\author{
FATORES ASSOCIADOS A INFECÇÕES EM CIRURGIA DA COLUNA VERTEBRAL
}

FACTORES ASOCIADOS A LAS INFECCIONES EN CIRUGÍA DE COLUMNA

Ana María Morales López ${ }^{1}$, Hugo Vilchis Sámano ${ }^{1}$

1. Instituto Mexicano del Seguro Social, Hospital de Ortopedia y Traumatología Lomas Verdes. Unidad Médica de Alta Especialidad, Naucalpan de Juárez, México.

\begin{abstract}
Objective: To identify the factors associated with postoperative infections in spinal surgery. Methods: Descriptive, retrospective, cross-sectional study conducted in the spine surgery department of the Medical Unit of High Specialty (UMAE) at the Hospital of Traumatology and Orthopedics Lomas Verdes, Mexican Institute of Social Security (IMSS) between January 01, 2013 and June 30,2014 through medical records of the service and the records of clinical care. Data were gathered in accordance with the records of patients with infection after spinal surgery. The factors considered were age group, etiologic agent, surgical site, type of treatment, bleeding volume and pharmacotherapy. Frequency and descriptive statistic was conducted. The rank sum test with the Wilcoxon test for a single sample was performed in different measurements; Pearson's correlation was calculated and all $p<0.05$ values were considered significant. Results: The sample was composed of 14 patients of which 11 were female (78.6\%) and 3 male (21.4\%) with predominance of surgical area in the lumbar and dorsolumbar region. There was a significant correlation between the surgical time and the amount of bleeding with $p<0.001$. Conclusions: It was clear that the infections present in patients after spinal surgery are multifactorial. However, in this study the correlation between time of surgery and bleeding amount had the highest importance and relevance.
\end{abstract}

Keywords: Infection; Postoperative complications; Spine.

\section{RESUMO}

Objetivo: Identificar os fatores associados a infecções pós-operatórias em cirurgia da coluna vertebral. Métodos: Estudo descritivo, retrospectivo, transversal, no serviço de cirurgia da coluna vertebral da Unidade Médica de Alta Especialidade (UMAE), Hospital de Traumatologia e Ortopedia Lomas Verdes, Instituto Mexicano de Seguro Social (IMSS), entre 1 de janeiro de 2013 e 30 de junho de 2014, por meio de registros de serviços e de registros do expediente clínico. Foram coletadas informações de acordo com os registros de pacientes com infecção pós-operatória em cirurgia da coluna vertebral. Os fatores considerados foram faixa etária, agente etiológico, local da cirurgia, tipo de tratamento, volume de sangramento e farmacoterapia. A estatística foi descritiva e de frequência. Realizou-se o teste de soma de postos com o teste de Wilcoxon para uma única amostra, em diferentes medições; a correlação de Pearson foi calculada e todos os valores de $p<0,05$ foram considerados significantes. Resultados: Foram reunidos 14 pacientes, dos quais eram 11 do sexo feminino (78,6\%) e 3 do sexo masculino (21,4\%), com predominância de área cirúrgica na região lombar e dorsolombar. Verificou-se correlação significante entre o tempo de cirurgia e o volume de sangramento de p < 0,001. Conclusões: Ficou claro que as infecções presentes em pacientes depois da cirurgia de coluna vertebral são multifatoriais. No entanto, neste estudo a correlação entre tempo de cirurgia e volume de sangramento tem a maior importância e relevância.

Descritores: Infecção; Complicações pós-cirúrgicas; Coluna vertebral.

\section{RESUMEN}

Objetivo: Identificar los factores asociados a las infecciones postoperatorias en cirugía de columna. Métodos: Se realizó un estudio descriptivo, retrospectivo, transversal, en el servicio de cirugía de columna de la Unidad Médica de Alta Especialidad (UMAE), Hospital de Traumatología y Ortopedia Lomas Verdes, Instituto Mexicano del Seguro Social (IMSS) entre 01 de enero de 2013 y 30 de junio de 2014 utilizando los registros del servicio y los de expediente clínico. Se recabó información de acuerdo a los registros de pacientes con infección postoperatoria en cirugía de columna. Los factores que se tomaron en cuenta fueron grupo etario, agente etiológico, área quirúrgica, tipo de tratamiento, volumen de sangrado, tiempo quirúrgico, farmacoterapia utilizada. Se realizó estadística de frecuencia y descriptiva. Se realizó la prueba de suma de rangos con la prueba de Wilcoxon para una sola muestra en diferentes mediciones; se realizó la correlación de Pearson y se tomó como significativo todo valor de $p<0,05$. Resultados: Fueron 14 pacientes de los cuales 11 del sexo femenino (78,6\%) y 3 del sexo masculino (21,4\%), con un predominio de área quirúrgica en la región lumbar y dorsolumbar. Se encontró una correlación significativa entre el tiempo quirúrgico y el volumen de sangrado de $p<0,001$. Conclusiones: Es claro que las infecciones presentes en pacientes después de cirugía de columna son de origen multifactorial. Sin embargo, en este estudio se encuentran de mayor significancia y relevancia la correlación de volumen de sangrado y el tiempo quirúrgico.

Descriptores: Infección; Complicaciones posoperatorias; Columna vertebral. 


\section{INTRODUCTION}

Most surgical instrumentation techniques have enabled improved outcomes in patients with various difficult-to-manage diseases of the spine. However, many procedures require prolonged surgical times, extensive approaches, and the placement of large instrumentations.

These factors can contribute to postoperative complications, including infection in the surgical area.

Postoperative infections can have devastating sequelae, including instrumentation failure, osteomyelitis, pseudoarthrosis, and significant medical problems.

Moreover, these infections are often difficult to diagnose and treat. ${ }^{1}$

Postoperative spinal infections are a potential problem in many cases following successful surgical procedures. ${ }^{2}$

It is reported that they can occur in between $0.7 \%$ and $12 \%$ of patients, ranging from $1 \%$ for lumbar discectomies to $1-2 \%$ for cervical spine surgery to $6 \%$ or more for lumbar spine surgery with instrumentation and/or fusion, resulting in a rise in morbidity, mortality, and high health care costs., ${ }^{2,3}$

There is a variety of risk factors for infections following spine surgery and they can be divided into factors dependent on the patient and factors dependent on the surgeon. ${ }^{2}$

Host factors include age, obesity, urinary incontinence, smoking, malnutrition, complete neurological deficit, revision surgery, use of non-steroidal anti-inflammatory medication, posterior surgical approach, tumor resection, increased bleeding above the permissible, prolonged surgical time, use of instrumentation, multilevel surgery, and/or vertebral fusion, and the presence of 3 or more comorbid illnesses. ${ }^{3-5}$

Included among the extrinsic factors are the absence of preoperative antibiotics, inadequate use of sterile techniques, and increased traffic in the operating room. 5,6

In addition, yet unproven factors using fluoroscopy and drainage are mentioned. ${ }^{2}$

Infections can occur both in deep and superficial tissues. The most common pathogens described are S. aureus and S. epidermidis. ${ }^{2}$ Diagnosing an infection in the surgical site following spine surgery is often difficult, as with many deep infections that can be present without symptoms.

In many patients, surgical site infections occur 2 to 3 weeks following the surgical procedure, with symptoms of increased pain at the level of the surgical area. There may be low-grade fever, erythema, edema, local hyperthermia, pain, and exudates.

Laboratory studies such as leukocyte count, C-reactive protein, erythrocyte sedimentation rate, and exudates cultures can help with the diagnosis, but often they are not conclusive. ${ }^{7}$

Treatment of postoperative infections in the spine depends on whether it is a superficial infection above the muscle fascia or involves fasciae and deep tissues down to the level of the spine.

In theory, the best treatment in cases of deep infection includes debridement of the wound, the removal of any instrumentation, and antibiotic therapy. However, in many cases removal of the instrumentation results in an unstable lesion and puts the patient at risk of neurological damage.

The decision as to whether to leave the instrumentation, to remove and relocate the implants, or to replace with new instrumentation in a second surgical procedure can be made during debridement. ${ }^{7}$

Antibiotic therapy plays a critical role in the treatment of the infection. ${ }^{7}$ Recognizing the preoperative risk factors can optimize and, in some cases, modify the preoperative condition of the patient., ${ }^{1,8}$

\section{MATERIAL AND METHODS}

With prior approval by the Institutional Review Board (R-2015-1501-2), a retrospective, transversal, descriptive study was conducted at the UMAE Hospital de Traumatología y Ortopedia "Lomas Verdes" of the Mexican Institute of Social Security during the period between January 1, 2013 and June 30, 2014.

The sample was selected based on data collected from the medical reports of patients of the spine surgery service during the period mentioned who had been diagnosed with a postoperative infectious process following spine surgery. There were 21 patients identified with the diagnosis mentioned whose clinical records were requested, 14 of whom met the inclusion criteria. Six patients without clinical records and 1 patient with an incorrectly registered diagnosis were excluded.

The final simple was made up of 14 patients.

The information for each of the patients was consolidated in a onepage data collection form.

\section{Statistical analysis}

Frequency and descriptive statistical analyses were performed. The Pearson correlation and the Spearman correlation were performed, considering a value of $p<0.05$ to be significant.

\section{Type of sampling}

Non-probability sampling. Fourteen patients met the selection criteria and were distributed as follows: 11 female (78.6\%) and 3 male (21.4\%).

Three patients had history of diabetes mellitus type 2 (21.4\%), 2 patients had history of systemic arterial hypertension (14.3\%), and one patient had rheumatoid arthritis (7.1\%).

The most prevalent surgical sites were the lumbar region in 5 patients (35.7\%) and the dorsolumbar region in 5 patients (35.7\%), followed by the dorsal area in 3 patients (21.4\%), and finally by the cervical region in 1 patient (7.1\%).

The posterior approach was used in all 14 patients (100\%). In terms of etiological agents, S. epidermidis was documented in 6 patients (42.9\%), S. aureus in 3 patients (21.4\%), S. haemolyticus in 2 patients (14.2\%), S. warneri in 1 patient (7.1\%), P. mirabilis in 1 patient $(7.1 \%)$, K. pneumoniae in 1 patient $(7.1 \%), P$. aeruginosa in 1 patient (7.1\%), E. coli in 1 patient $(7.1 \%)$, and A. baumaniil haemolyticus in 1 patient $(7.1 \%)$.

We found a significant correlation between surgical time and bleeding volume with $p<0.001$. (Figures 1 and 2)

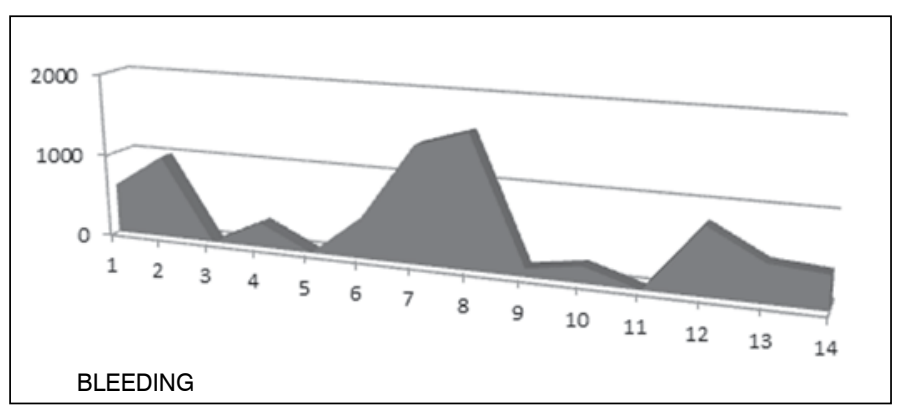

Figure 1. Level of bleeding by patient evaluated.

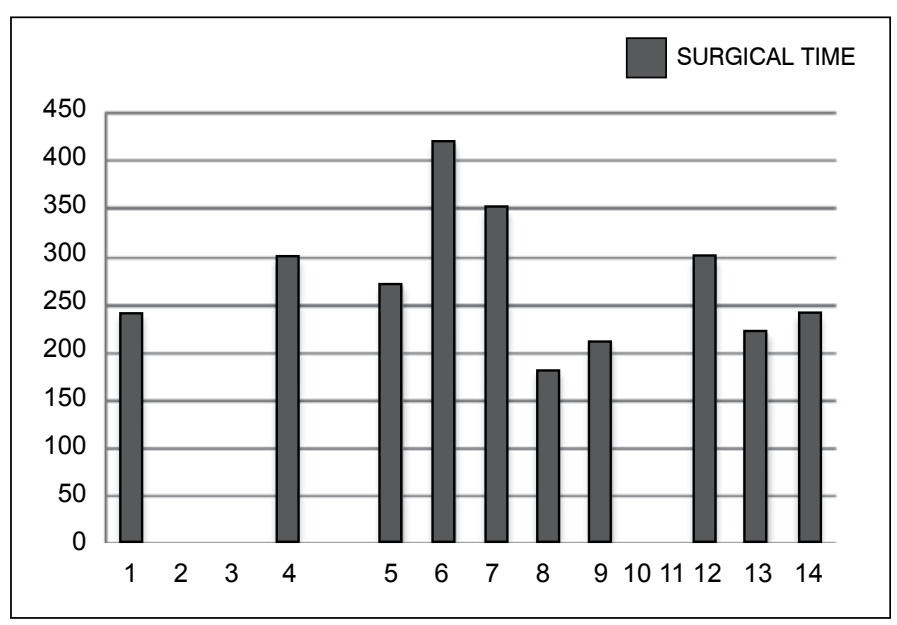

Figure 2. Surgical time by patient evaluated. 


\section{DISCUSSION}

Postoperative spinal infections are frequently a potential problem following successful surgical procedures. ${ }^{2}$

According to reports published by Abdul-Jabbar ${ }^{9}$, as well as by Pull ter Gunne ${ }^{7}$, the most commonly isolated agent in postoperative infections of the spine is $S$. aureus, followed by S. epidermidis with $E$. coli identified less frequently.

Our results show that in our environment the most common etiological agent was S. epidermidis followed by S. aureus and less frequently by $S$. haemolyticus, reflecting an inverse relationship to the results reported in the literature.

The correlation that exists between surgical time and bleeding volume in this study confirms and supports the findings of Pull ter Gunne. ${ }^{3}$

\section{CONCLUSIONS}

It is clear that the infections present in patients following spine surgery have multifactorial origins, however, in this study we found greater significance and relevance in the correlation between bleeding volume and surgical time.
We also determined that the most common etiological agent in our population was $S$. epidermidis, with $S$. aureus occurring less frequently, which is the opposite of the results reported in the literature.

However, in our study we found an apparent symbiosis between $S$. epidermidis and $S$. aureus.

Thus, by identifying these risk factors, we can design a protocol and treatment guidelines to manage and reduce infections in patients following spine surgery.

\section{ACKNOWLEDGEMENTS}

We would like to thank the Spine Service of the Hospital de Traumatología y Ortopedia Lomas Verdes of the Mexican Institute of Social Security for their support, and the records department of the same institution for their data collection support.

All the authors declare that there are no potential conflicts of interest regarding this article.

AUTHORS' CONTRIBUTION: Each author made significant individual contributions to the preparation of the manuscript. AMML developed the concept and the study design. HVS collected the data and analyzed.

\section{REFERENCES}

1. Fang A, Hu SS, Endres N, Bradford DS. Risk factors for infection after spinal surgery. Spine. 2005;30(12):1460-5.

2. Frymore J, Wiesel S, The Adult a Pediatric Spine, Lippincott Williams \& Wilkins, $3^{\text {a }}$ edición, Philadelphia USA, 2004, Cap 10, 184-7.

3. Pull ter Gunne AF, Cohen DB. Incidence, prevalence, and analysis of risk factors for surgical site infection following adult spinal surgery. Spine. 20091;34(13):1422-8.

4. Gruskay J, Kepler C, Smith J, Radcliff K, Vaccaro A. Is surgical case order associated with increased infection rate after spine surgery? Spine. 2012;37(13):1170-4.

5. Oren B., Vaccaro A., et.al., Risk Factors for Surgical Site Infection in the Patient With the Spinal Surgery, SPINE, 2003, 28(13), 1475-80.

6. Schuster JM, Rechtine G, Norvell DC, Dettori JR. The influence of perioperative risk factors and therapeutic interventions on infection rates after spine surgery: a systematic review. Spine. 2010;35(Suppl 9):S125-37.

7. Pull ter Gunne AF, Mohamed AS, Skolasky RL, van Laarhoven CJ, Cohen DB. The presentation, incidence, etiology, and treatment of surgical site infections after spinal surgery. Spine. 2010;35(13):1323-8.
8. Blam OG, Vaccaro AR, Vanichkachorn JS, Albert TJ, Hilibrand AS, Minnich JM et al. Risk factors for surgical site infection in the patient with spinal injury. Spine. 2003;28(13):1475-80.

9. Abdul-Jabbar A, Berven SH, Hu SS, Chou D, Mummaneni PV, Takemoto S, et al. Surgical site infections in spine surgery: identification of microbiologic and surgical characteristics in 239 cases. Spine. 2013;38(22):E1425-31.

10. Veeravagu A, Patil CG, Lad SP, Boakye M. Risk factors for postoperative spinal wound infections after spinal decompression and fusion surgeries. Spine. 2009;34(17):1869-72.

11. Abdul-Jabbar A, Takemoto S, Weber MH, Hu SS, Mummaneni PV, Deviren V, et al Surgical site infection in spinal surgery: description of surgical and patient-based risk factors for postoperative infection using administrative claims data. Spine. 2012;37(15):1340-5.

12. Pull ter Gunne AF, Hosman AJ, Cohen DB, Schuetz M, Habil D, van Laarhoven CJ, et al. A methodological systematic review on surgical site infections following spinal surgery: part 1: risk factors. Spine. 2012;37(24):2017-33. 